\title{
The effect of pyridinecarboxylate chelating groups on the stability and electronic relaxation of gadolinium complexes $\dagger$
}

\author{
Nicholas Chatterton, ${ }^{a}$ Christelle Gateau, ${ }^{a}$ Marinella Mazzanti, ${ }^{* a}$ Jacques Pécaut, ${ }^{b}$ \\ Alain Borel, ${ }^{c}$ Lothar Helm ${ }^{c}$ and André Merbach ${ }^{c}$ \\ a Laboratoire de Reconnaissance Ionique, Service de Chimie Inorganique et Biologique, \\ Département de Recherche Fondamentale sur la Matière Condensée, CEA-Grenoble, 38054, \\ Grenoble, Cedex09, France.E-mail: mazzanti@drfmc.ceng.cea.fr \\ ${ }^{b}$ Laboratoire de Coordination et Chiralité, Service de Chimie Inorganique et Biologique, \\ Département de Recherche Fondamentale sur la Matière Condensée, CEA-Grenoble, 38054, \\ Grenoble, Cedex 09, France \\ ${ }^{c}$ Laboratoire de Chimie Inorganique et Bioinorganique, Ecole Polytechnique Fédérale de \\ Lausanne, EPFL-BCH, CH-1015, Lausanne, Switzerland
}

Received 19th October 2004, Accepted 26th January 2005

First published as an Advance Article on the web 10th February 2005

The ligand $N, N^{\prime}$-bis[(6-carboxy-2-pyridylmethyl]ethylenediamine- $N, N^{\prime}$-diacetic acid $\left(\mathrm{H}_{4}\right.$ bpeda) was synthesised using an improved procedure which requires a reduced number of steps and leads to a higher yield with respect to the published procedure. It was obtained in three steps from diethylpyridine-2,6-dicarboxylate and commercially available ethylenediamine- $N, N^{\prime}$-diacetic acid with a total yield of $\sim 20 \%$. The crystal structure of the hexa-protonated form of the ligand which was determined by X-ray diffraction shows that the four carboxylates and the two amines are protonated. The crystal structure of the polynuclear complex $\left[\mathrm{Gd}(\text { bpeda })\left(\mathrm{H}_{2} \mathrm{O}\right)_{2}\right]_{3}\left[\mathrm{Gd}_{(}\left(\mathrm{H}_{2} \mathrm{O}\right)_{6}\right]_{2} \mathrm{Cl}_{3}(2)$, isolated by slow evaporation of a 1:1 mixture of $\mathrm{GdCl}_{3}$ and $\mathrm{H}_{4}$ bpeda at $\mathrm{pH} \sim 1$, was determined by X-ray diffraction. In complex 2 three $\left[\mathrm{Gd}(\right.$ bpeda $\left.)\left(\mathrm{H}_{2} \mathrm{O}\right)_{2}\right]$ units, containing a $\mathrm{Gd}(\mathrm{III})$ ion ten-coordinated by the octadentate bpeda and two water molecules, are connected in a pentametallic structure by two hexa-aquo $\mathrm{Gd}^{3+}$ cations through four carboxylato bridges. The protonation constants $\left(\mathrm{p} K_{\mathrm{a} 1}=2.9(1), \mathrm{p} K_{\mathrm{a} 2}=3.5(1), \mathrm{p} K_{\mathrm{a} 3}=5.2(2)\right.$, and $\left.\mathrm{p} K_{\mathrm{a} 4}=8.5(1)\right)$ and the stability constants of the complexes formed between $\mathrm{Gd}(\mathrm{III})$ and $\mathrm{Ca}(\mathrm{II})$ ions and $\mathrm{H}_{4}$ bpeda $\left(\log \beta_{\mathrm{GdL}}=15.1(3) ; \log \beta_{\mathrm{CaL}}=9.4(1)\right)$ were determined by potentiometric titration. The unexpected decrease in the stability of the gadolinium complex and of the calcium complex of the octadentate ligand bpeda ${ }^{4-}$ with respect to the hexadentate ligand edta ${ }^{4-}$ has been interpreted in terms of an overall lower contribution to stability of the metal-nitrogen interactions. The EPR spectra display very broad lines (apparent $\Delta H_{\mathrm{pp}} \sim 800-1200 \mathrm{G}$ at X-band and $90-110 \mathrm{G}$ at Q-band depending on the temperature), indicating a rapid transverse electron spin relaxation. At X-band, Gd(bpeda) is among the fastest relaxing $\mathrm{Gd}^{3+}$ complexes to date suggesting that the presence of pyridinecarboxylate chelating groups in itself does not lead to slow electron relaxation.

\section{Introduction}

The application of gadolinium complexes containing polyaminocarboxylate ligands as contrast agents in magnetic resonance imaging (MRI), a primary medical diagnostic technique, has prompted a large number of studies. ${ }^{1-6}$ The key property of an efficient contrast agent is its ability to enhance the relaxation rate of solvent water protons (relaxivity, $r_{\mathrm{lp}}$ ). The relaxivity of current clinical contrast agents is much lower than theoretically possible due to lack of simultaneous optimisation of all the parameters determining the relaxation enhancement. Higher relaxivity is required for the next generation of site-specific MRI contrast agents. High relaxivity can be obtained in the presence of a high number of inner sphere water molecules allied with optimized water exchange rate, a long rotational correlation time and a long electronic relaxation time. Furthermore due to the extreme toxicity of the gadolinium ion the stability of MRI contrast agents is critical since the toxicity of contrast agents is directly related to the concentration of free gadolinium in vivo.

Gadolinium complexes of tripodal or tetrapodal ligands containing pyridinecarboxylate arms have recently shown in-

$\dagger$ Electronic supplementary information (ESI) available: Tables S1S3 containing peak-to-peak width and central field as a function of temperature for the EPR spectra of the aqueous [Gd(bpeda)]K complex. See http://www.rsc.org/suppdata/dt/b4/b416150e/ teresting relaxation properties. Furthermore the facile functionalization of the pyridine rings makes these ligands attractive for the access to macromolecular contrast agents with longer correlation times and therefore higher relaxivity.

We have recently reported the two new tripodal ligands tpaa and tpatcn (Scheme 1) containing three pyridinecarboxylate arms which yield low-molecular weight gadolinium complexes with high relaxivity. The heptadentate tripodal ligand tpaa $\left(\mathrm{H}_{3}\right.$ tpaa $=\alpha, \alpha^{\prime}, \alpha^{\prime \prime}$-nitrilotri(6-methyl-2-pyridinecarboxylic acid $\left.)\right)$ contains three pyridinecarboxylate arms connected to a nitrogen atom. ${ }^{7,8}$ The ligand tpaa forms a rather insoluble gadolinium complex which has shown a remarkably higher value of relaxivity $\left(r_{1 \mathrm{p}}=13.3 \mathrm{mM}^{-1} \mathrm{~s}^{-1}\right.$ at $298 \mathrm{~K}$ and at $\left.60 \mathrm{MHz}\right)$ than those found in the clinically used contrast agents based on mono-aqua complexes of octacoordinate ligands such as $\left[\mathrm{Gd}(\mathrm{dtpa})\left(\mathrm{H}_{2} \mathrm{O}\right)\right]^{2-}$ or $\left[\mathrm{Gd}(\operatorname{dota})\left(\mathrm{H}_{2} \mathrm{O}\right)\right]^{-},\left(4.3-4.7 \mathrm{mM}^{-1} \mathrm{~s}^{-1}, 298 \mathrm{~K}, 20 \mathrm{MHz}\right)$. $\mathrm{The}$ observed high relaxivity was attributed to the shorter $\mathrm{Gd}-\mathrm{O}_{\text {water }}$ distance and to a possible coordination equilibrium between species with two and three bound water molecules. Conversely the similarly high relaxivity $\left(12.3 \mathrm{mM}^{-1} \mathrm{~s}^{-1}, 298 \mathrm{~K}, 20 \mathrm{MHz}\right)$ of the bis-aqua complex $\left[\mathrm{Gd}(\operatorname{ado} 3 \mathrm{a})\left(\mathrm{H}_{2} \mathrm{O}\right)_{2}\right]^{3-9}$ has been interpreted in terms of a substantial second sphere contribution. The

$\$ \mathrm{H}_{4}$ dota $=1,4,7,10$-Tetraazacyclododecane- $N, N^{\prime}, N^{\prime \prime}, N^{\prime \prime \prime}$-tetraacetic acid, $\mathrm{H}_{5} \mathrm{dtpa}=$ diethylenetriaminepentaacetic acid, $\mathrm{H}_{3}$ do3a $=1,4,7,10$ tetraazacyclododecane-1,4,7-triacetic acid. 
<smiles>O=C(O)CN(CC(=O)O)CC(=O)O</smiles>

$\mathrm{H}_{3}$ nta<smiles>O=C(O)CN(CCN(CC(=O)O)CC(=O)O)CC(=O)O</smiles>

$\mathrm{H}_{4}$ edta

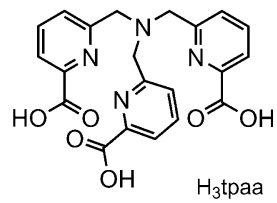

$\mathrm{H}_{3}$ tpaa<smiles>O=C(O)CN(CCN(CC(=O)O)Cc1ccccn1)Cc1ccccn1</smiles><smiles></smiles>

$\mathrm{H}_{3}$ tpatcn<smiles>CCCCCCCCCCCCCCCCCCC(=O)c1cccc(CN(CCN(CC(=O)O)Cc2cccc(C(=O)O)n2)CC(=O)O)n1</smiles>

Scheme 1

nonadentate ligand 1,4,7-tris[(6-carboxypyridin-2-yl)methyl]1,4,7-triazacyclononane (tpatcn $\mathrm{H}_{3}$ ) contains three pyridinecarboxylate arms connected to the 1,4,7-triazacyclonane core. It yields a nonacoordinated gadolinium complex which does not contain coordinated water molecules, but displays a high low field (<1 MHz) relaxivity $\left(5.3 \mathrm{mM}^{-1} \mathrm{~s}^{-1}\right.$ at $0.02 \mathrm{MHz}$ at $\left.298 \mathrm{~K}\right)$ which has been interpreted in terms of a favorable electronic relaxation rate. Although the optimization of the electronic relaxation is very important in order to achieve improved relaxivity, the influence of the coordination sphere on the electronic relaxation of the gadolinium ion is poorly understood.

In an effort to gain a better understanding of the factors governing the stability and the electronic spin relaxation in polypyridinecarboxylate complexes the ligand $\mathrm{H}_{4}$ bpeda has been prepared. While this work was in progress the synthesis of this ligand, the solution structure determined by detailed paramagnetic NMR and luminescence studies and the relaxivity of its lanthanide complexes were reported by Mato-Iglesias and coworkers. ${ }^{10}$ The studies described by this group show that the ligand $\mathrm{H}_{4}$ bpeda yields nonacoordinated complexes of gadolinium with one water molecule bound to the gadolinium ion. This complex shows water proton relaxivity and water exchange rate similar (or slightly favorable) to commercial contrast agents (such as $\left[\mathrm{Gd}(\mathrm{dtpa})\left(\mathrm{H}_{2} \mathrm{O}\right)\right]^{2-}$ or $\left[\mathrm{Gd}(\operatorname{dota})\left(\mathrm{H}_{2} \mathrm{O}\right)\right]^{-}$).

However high stability is imperative for gadolinium complexes considered as contrast agents to prevent toxicity. We have studied how the presence of pyridinecarboxylate units affect stability and electronic relaxation. Here we report an improved synthesis of the ligand $\mathrm{H}_{4}$ bpeda, the protonation constants and the formation constants for the complexation of $\mathrm{H}_{4}$ bpeda with $\mathrm{Gd}$ (III) and $\mathrm{Ca}(\mathrm{II})$ along with EPR spectroscopy of the gadolinium complex.

\section{Experimental}

\section{General information}

${ }^{1} \mathrm{H}$ and ${ }^{13} \mathrm{C}$ NMR spectra were recorded on a Varian Mercury 400 spectrometer. Chemical shifts are reported in ppm with solvent or 3-(trimethylsilyl)-1-propane-sulfonic acid, sodium salt as internal reference. Mass spectra were obtained with a Finnigan LCQ-ion trap equipped with an electrospray source. Elemental analyses were performed by the Service Central d'Analyses (Vernaison, France).

Solvents and starting materials were obtained from Aldrich, Fluka, Acros and Alfa and used without further purification. 6-Chloromethylpyridine-2-carboxylic acid ethyl ester was obtained from the commercially available 2,6-dipicolinic acid according to a published procedure. ${ }^{11}$

\section{Synthesis of the ligand $\mathrm{H}_{4}$ bpeda}

$N, N^{\prime}$ - Bis [ (6-carboxypyridin-2-yl) methyl] ethylenediamine$N, N^{\prime}$-diacetic acid. To a solution of 6-chloromethylpyridine- 2-carboxylic acid ethyl ester $(0.451 \mathrm{~g}, 2.26 \mathrm{mmol})$ in anhydrous acetonitrile $(10 \mathrm{~mL})$, ethylenediamine- $N, N^{\prime}$-diacetic acid $(0.181 \mathrm{~g}, 1.03 \mathrm{mmol}), \mathrm{K}_{2} \mathrm{CO}_{3}(0.312 \mathrm{~g}, 2.26 \mathrm{mmol})$ and $\mathrm{KI}$ $(0.375 \mathrm{~g}, 2.26 \mathrm{mmol})$ were successively added under argon atmosphere. The reaction mixture was refluxed for $16 \mathrm{~h}$. After filtration and evaporation of the solvent, the resulting crude product $(0.82 \mathrm{~g})$ was chromatographed $(20 \mathrm{ml}$ aluminium oxide, $\mathrm{CH}_{2} \mathrm{Cl}_{2}$-ethanol: gradient from $100: 0$ to $\left.90: 10\right)$ to eliminate the inorganic salts and starting material. After evaporation of the solvent a yellow oil was obtained $(0.340 \mathrm{~g}$ containing the condensation product and a product identified as the lactam in approximately $50: 50$ ratio) which was used without further purification. The oil was dissolved and refluxed overnight in a $6 \mathrm{M} \mathrm{HCl}$ aqueous solution $(30 \mathrm{~mL})$. After evaporation of the solvent to $\sim 5 \mathrm{ml}$ the resulting precipitate was collected and dried under vacuum to yield $\mathrm{H}_{4}$ bpeda. $4 \mathrm{HCl} \cdot 2 \mathrm{H}_{2} \mathrm{O}$ as a white solid (0.206 g, 32\%). NMR ( $\left.\mathrm{D}_{2} \mathrm{O}, 400 \mathrm{MHz}, \mathrm{pH}=7.14\right)$ : $\delta 3.22$ (s, 4H, H10); 3.44 (s, 4H, H8); 4.19 (s, 4H, H7); 7.55 (d, $J=7.6 \mathrm{~Hz}, 2 \mathrm{H}, \mathrm{H} 5) ; 7.82(\mathrm{~d}, J=7.6 \mathrm{~Hz}, 2 \mathrm{H}, \mathrm{H} 3) ; 8.86$ $(\mathrm{t}, J=7.6 \mathrm{~Hz}, 2 \mathrm{H}, \mathrm{H} 4) \cdot{ }^{13} \mathrm{C}$ NMR $\left(\mathrm{D}_{2} \mathrm{O}, 100 \mathrm{MHz}\right): \delta 51.6$ $\left(\mathrm{CH}_{2}\right) ; 56.4\left(\mathrm{CH}_{2}\right) ; 57.8\left(\mathrm{CH}_{2}\right) ; 125.8(C \mathrm{Hpy}) ; 128.4(C \mathrm{Hpy})$; 142.9 (CHpy); 147.4 (Cpy); 152.0 (Cpy); 166.4 ( $C \mathrm{OOH}) ; 172.1$ (COOH). ES-MS: $m / z$ 469.1 [M $+\mathrm{Na}]^{+} ; 447.1[\mathrm{M}+\mathrm{H}]^{+}$; $403.1\left[\mathrm{M}+\mathrm{H}-\mathrm{COO}^{+}\right.$. ES-MS: $m / z$ 445.0 $[\mathrm{M}-\mathrm{H}]^{-} ; 401.0$ $\left[\mathrm{M}-\mathrm{H}-\mathrm{COO}^{-}\right.$; $357.1\left[\mathrm{M}-\mathrm{H}-2 \mathrm{COO}^{-}\right.$. Anal. Calc. for $\mathrm{H}_{4}$ bpeda. $4 \mathrm{HCl} \cdot 2 \mathrm{H}_{2} \mathrm{O}, \mathrm{C}_{20} \mathrm{H}_{30} \mathrm{~N}_{4} \mathrm{O}_{8}: 38.23, \mathrm{H} 4.81, \mathrm{~N} 8.92$. Found: C 38.49, H 4.88, N 9.00\%.

\section{Preparation of the complexes}

[ $\mathbf{L n}(\mathbf{b p e d a})](\mathbf{L n}=\mathbf{E u}, \mathbf{G d}) . \quad$ A solution of $\mathrm{LnCl}_{3} \cdot 6 \mathrm{H}_{2} \mathrm{O}(\mathrm{Ln}=$ $\mathrm{Eu}, \mathrm{Gd}$, $)(40.7 \mathrm{mmol})$ in water $(2 \mathrm{~mL})$ was added to a solution of $\mathrm{H}_{4}$ bpeda (40.7 mmol) in water $(2 \mathrm{~mL})$. The $\mathrm{pH}$ of the resulting mixture was adjusted $(\mathrm{pH} \sim 6)$ by adding aqueous $\mathrm{KOH}$ solution $(0.445 \mathrm{M})$. The solution was stirred at room temperature overnight. After evaporation of the water the resulting solid was suspended in ethanol. The resulting yellow suspension was refrigerated at $0{ }^{\circ} \mathrm{C}$ overnight. $\mathrm{KCl}$ was eliminated by filtration. The resulting solution was evaporated to small volume $(0.5 \mathrm{ml})$. Addition of isopropyl alcohol $(20 \mathrm{ml})$ yielded the bpeda complexes of $\mathrm{Gd}$ and Eu as yellow microcrystalline solids (65$75 \%)$.

ES-MS: $m / z 602[\mathrm{Gd}(\text { bpeda })+\mathrm{H}]^{+}$. Anal. Calc. for $\left[\mathrm{Gd}(\right.$ bpeda $\left.)\left(\mathrm{H}_{2} \mathrm{O}\right)\right] \mathrm{K} \cdot 2.5 \mathrm{H}_{2} \mathrm{O}, \mathrm{C}_{20} \mathrm{H}_{25} \mathrm{GdN}_{4} \mathrm{O}_{11.5} \mathrm{~K}(M=702.4)$ :

C 34.16, H 3.55, N 7.97. Found: C 34.36, H 3.67, N 7.78\%.

ES-MS: $m / z 597[\mathrm{Eu}(\text { bpeda })+\mathrm{H}]^{+}$. Anal. Calc. for $\left[\mathrm{Eu}(\right.$ bpeda $\left.)\left(\mathrm{H}_{2} \mathrm{O}\right)\right] \mathrm{K} \cdot 3.5 \mathrm{H}_{2} \mathrm{O}, \mathrm{C}_{20} \mathrm{H}_{27} \mathrm{EuN}_{4} \mathrm{O}_{12,5} \mathrm{~K}(M=715.1)$ : C 33,56, H 3.77, N 7.83. Found: C 33.61, H 3.69, N 7.73\%.

\section{X-Ray crystallography}

All diffraction data were taken using a Bruker SMART CCD area detector three-circle diffractometer (Mo-K $\alpha$ radiation, 
Table 1 Crystallographic data for the structures of $\mathbf{1}$ and $\mathbf{2}$

\begin{tabular}{|c|c|c|}
\hline & 1 & $2 \cdot 0.5 \mathrm{MeCN} \cdot 18.5 \mathrm{H}_{2} \mathrm{O}$ \\
\hline Formula & $\mathrm{C}_{20} \mathrm{H}_{32} \mathrm{Cl}_{2} \mathrm{~N}_{4} \mathrm{O}_{12}$ & $\mathrm{C}_{66} \mathrm{H}_{127} \mathrm{Cl}_{3} \mathrm{Gd}_{5} \mathrm{~N}_{12.50} \mathrm{O}_{60.50}$ \\
\hline$M_{\mathrm{r}}$ & 591.40 & 2956.4 \\
\hline Crystal system & Triclinic & Monoclinic \\
\hline Space group & $P \overline{1}$ & $P 2_{1}$ \\
\hline$a / \AA$ & $7.159(2)$ & $15.913(1)$ \\
\hline$b / \AA$ & $8.014(3)$ & $19.280(1)$ \\
\hline$c / \AA$ & $24.123(8)$ & $17.363(1)$ \\
\hline$a /^{\circ}$ & $84.739(6)$ & 90 \\
\hline$\beta /^{\circ}$ & $87.999(6)$ & $98.281(1)$ \\
\hline$\gamma /{ }^{\circ}$ & $75.022(6)$ & 90 \\
\hline$V / \AA^{3}, Z$ & $1331.3(7), 2$ & $5271.6(6), 2$ \\
\hline$\lambda / \AA$ & 0.71073 & 0.71073 \\
\hline$D_{\mathrm{c}} / \mathrm{g} \mathrm{cm}^{-3}$ & 1.475 & 1.863 \\
\hline$\mu(\mathrm{Mo}-\mathrm{K} \alpha) / \mathrm{mm}^{-1}$ & 0.312 & 3.285 \\
\hline$T / \mathrm{K}$ & $293(2)$ & $193(2)$ \\
\hline$R_{1}, w R_{2}^{a}$ & $0.0436,0.1043$ & $0.0788,0.2056$ \\
\hline
\end{tabular}

${ }^{a}$ Structure was refined on $F_{\mathrm{o}}{ }^{2}$ using all data: $w R_{2}=\left[\sum\left[w\left(F_{\mathrm{o}}{ }^{2}-\right.\right.\right.$ $\left.\left.\left.F_{\mathrm{c}}{ }^{2}\right)^{2}\right] / \sum w\left(F_{\mathrm{o}}{ }^{2}\right)^{2}\right]^{1 / 2}$, where $w^{-1}=\left[\sum\left(F_{\mathrm{o}}{ }^{2}\right)+(a P)^{2}+b P\right]$ and $P=$ $\left[\max \left(F_{\mathrm{o}}{ }^{2}, 0\right)+2 F_{\mathrm{c}}{ }^{2}\right] / 3$.

graphite monochromator, $\lambda=0.71073 \AA$ ). To prevent evaporation of co-crystallised water molecules the crystals were coated with a light hydrocarbon oil. The cell parameters were obtained with intensities detected on three batches of 15 frames with a $180 \mathrm{~s}$ exposure time for $\mathbf{1}$ and $10 \mathrm{~s}$ for $\mathbf{2}$. The crystaldetector distance was $5 \mathrm{~cm}$. For three settings of $\Phi, 1271$ narrow data frames for $\mathbf{1}$ and $\mathbf{2}$ were collected for $0.3^{\circ}$ increments in $\omega$ with a $180 \mathrm{~s}$ exposure time for 1 and $10 \mathrm{~s}$ for $\mathbf{2}$. At the end of data collection, the first 50 frames were recollected to establish that crystal decay had not taken place during the collection. Unique intensities with $I>10 \sigma(I)$ detected on all frames using the Bruker Smart program ${ }^{12}$ were used to refine the values of the cell parameters. The substantial redundancy in data allows empirical absorption corrections to be applied using multiple measurements of equivalent reflections with the SADABS Bruker program. ${ }^{12}$ Space groups were determined from systematic absences, and they were confirmed by the successful solution of the structure for $\mathbf{1}$. For $\mathbf{2}$ the solution of the structure was attempted in different space groups. The best results were obtained with the space group $P 2_{1}$ (Table 1 ).

CCDC reference numbers 253404 and 253405.

See http://www.rsc.org/suppdata/dt/b4/b416150e/ for crystallographic data in CIF or other electronic format.

The structures were solved by direct methods using the SHELXTL 5.03 package $^{13}$ and all atoms, including hydrogen atoms for complex 1, were found by difference Fourier syntheses. All non-hydrogen atoms of $\mathbf{1}$ were anisotropically refined on $F^{2}$. Hydrogen atoms were refined isotropically. Due to the poor quality of the crystals, the structure of $\mathbf{2}$ is not of high quality. Solution of the structure in space group $P 2_{1}$ resulted in the presence of unusual thermal ellipsoids for several atoms. This, together with the overall structure, suggests the presence of an additional twofold axis parallel to the $b$ direction. However this is not compatible with the monoclinic cell which is the only cell that indexes all the diffraction intensities. Therefore the atoms C3, C4, C8, C9, C21, C214 were refined isotropically. All co-crystallized solvents were located by difference Fourier synthesis. In spite of several attempts using different disorder models, the refinement of the solvent molecules remained unstable. Therefore the solvents were not refined and isotropic displacement parameters were fixed at $0.05 \AA$.

\section{Potentiometric titrations}

Ligand protonation constants and metal ion stability constants with $\mathrm{H}_{4}$ bpeda were determined by potentiometric titrations. Gd(III) solutions were prepared by dissolving the appropriate amounts of $\mathrm{GdCl}_{3} \cdot 6 \mathrm{H}_{2} \mathrm{O}$ (Aldrich) in water. The exact $\mathrm{Gd}^{3+}$ ion concentration was determined by colorimetric titration in acetate buffer $(\mathrm{pH}=4.5)$ using standardized $\mathrm{H}_{2} \mathrm{Na}_{2}$ edta solution (Aldrich) and xylenol orange as the indicator. $\mathrm{Ca}(\mathrm{II})$ solutions were prepared by dissolving $\mathrm{CaCl}_{2} \cdot 2 \mathrm{H}_{2} \mathrm{O}$ (Aldrich) in water. The exact $\mathrm{Ca}^{2+}$ ion concentration was determined by colorimetric titration in $\mathrm{KOH}$ using standardized $\mathrm{H}_{2} \mathrm{Na}_{2}$ edta solution (Aldrich) and calgonite as the indicators. $20 \mathrm{~mL}$ solutions of $\mathrm{H}_{4}$ bpeda $\left(5.0 \times 10^{-4} \mathrm{M}\right)$ alone, acidified $(\mathrm{pH} \sim 2-5)$ $0.9: 1$ metal-ligand mixtures $\left([\mathrm{L}]=5.0 \times 10^{-4} \mathrm{M}\right)$ or $1: 1: 0.9$ edta-ligand-metal mixtures $\left([\mathrm{L}] \approx 5.0 \times 10^{-4} \mathrm{M}\right)$ were titrated in a thermostated cell $\left(25.0 \pm 0.1^{\circ} \mathrm{C}\right)$ under a stream of argon with a $0.1 \mathrm{M} \mathrm{KOH}$ solution added by means of a $5 \mathrm{~mL}$ piston burette (Metrohm). The ionic strength was fixed with $\mathrm{KCl}(\mu=0.1 \mathrm{M})$. Titrations were carried out with a Metrohm 751 GPD Titrino potentiometer equipped with a combined $\mathrm{pH}$ glass electrode (Metrohm). Calibration of the electrode system was performed prior to each measurement. The electromotive force is given by $E=E^{\circ}+s \mathrm{p}\left[\mathrm{H}^{+}\right]$and both $E^{\circ}$ and $s$ were determined by titrating a known amount of $\mathrm{HCl}$ by $0.1 \mathrm{M} \mathrm{KOH}$ at $\mu=0.1 \mathrm{M}(\mathrm{KCl})$, using the acid range of the titration. The value used for the ion product of water is $\log K_{\mathrm{w}}=13.77 .{ }^{14}$ More than 70 data points were collected for each experiment.

The data were mathematically treated by the program HYPERQUAD2000..$^{15,16}$ All values and errors represent the average of at least three independent experiments.

\section{NMR Titrations}

$\sim 10^{-2} \mathrm{M}$ solutions of $\mathrm{H}_{4}$ bpeda were prepared in $\mathrm{D}_{2} \mathrm{O}$ in presence of tert-butyl alcohol, as reference. Sample solutions with different $\mathrm{pH}$ values were prepared by adding dilute $\mathrm{NaOD}$ $\mathrm{D}_{2} \mathrm{O}$ or dilute $\mathrm{DCl}-\mathrm{D}_{2} \mathrm{O}$ (Aldrich). The $\mathrm{pH}$ values of the solutions were determined with a MeterLab, PHM $220 \mathrm{pH}$ Meter. The ionic strength was not adjusted.

\section{EPR Measurements}

A $23 \mathrm{mM}[\mathrm{Gd}(\text { bpeda })]^{-}$solution was prepared by dissolving $13 \mathrm{mg}$ of $\mathrm{K}\left[\mathrm{Gd}\left(\right.\right.$ bpeda) $\left.\left(\mathrm{H}_{2} \mathrm{O}\right)_{2}\right] \cdot 1.5 \mathrm{H}_{2} \mathrm{O}$ into $0.794 \mathrm{~g}$ of bidistilled water. EPR Spectra were recorded on a Bruker Elexsys E500 system operating at X- and Q-band $(9.4$ and $34 \mathrm{GHz}$, respectively). The microwave frequency was measured using a frequency counter embedded in the standard microwave bridge (X-band) or an external Hewlett-Packard 5353B frequency counter (Q-band). The temperature was varied between 274 and $340 \mathrm{~K}$ using boiling nitrogen flowing over a thermoresistor, and measured with a standard substitution technique.

The peak-to-peak widths $\Delta H_{\mathrm{pp}}$ and central fields $B_{\mathrm{c}}$ were determined by fitting the digitally recorded spectra to Lorentzian derivatives, with simultaneous baseline and phase correction. ${ }^{17}$

\section{Results and discussion}

\section{Synthesis and molecular structure of the ligand bpeda}

$N, N^{\prime}$-Bis[(6-carboxy-2-pyridylmethyl]ethylenediamine- $N, N^{\prime}$ diacetic acid. ( $\mathrm{H}_{4}$ bpeda) was obtained by the group of Mato-Iglesias in a five-step procedure from dimethylpyridine2,6 -dicarboxylate with a total yield of $10 \%$. We have found that the ligand can be obtained in three steps from diethylpyridine2,6-dicarboxylate and commercially available ethylenediamine$N, N^{\prime}$-diacetic acid with a total yield of $19.8 \%$ (Scheme 2). The 6-chloromethylpyridine-2-carboxylic acid ethyl ester was prepared in $62 \%$ yield following the published procedure. ${ }^{11}$ The 6-chloromethylpyridine-2-carboxylic acid ethyl ester was reacted with ethylenediamine- $N, N^{\prime}$-diacetic acid in the presence of $\mathrm{K}_{2} \mathrm{CO}_{3}$ and $\mathrm{KI}$ to give a mixture of the expected condensation product and of a byproduct identified as the lactam in approximately $50: 50$ ratio. Hydrolysis of the raw mixture with 


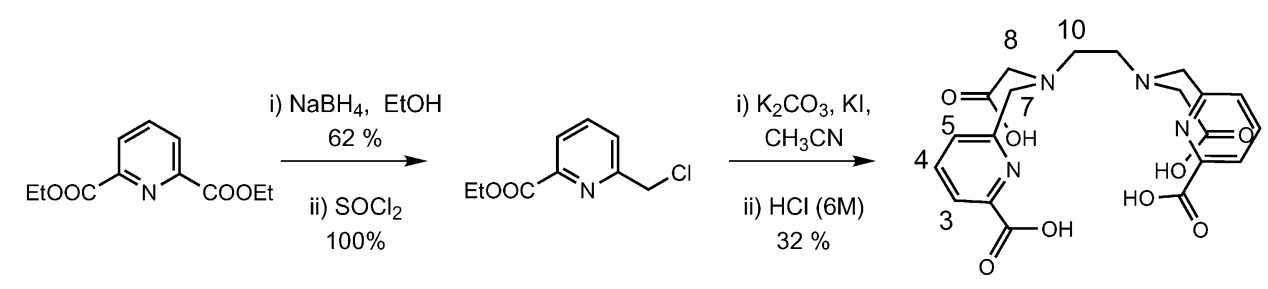

Scheme 2

$\mathrm{HCl}(6 \mathrm{M})$ resulted in the isolation of $\mathrm{H}_{4}$ bpeda. $4 \mathrm{HCl} \cdot 2 \mathrm{H}_{2} \mathrm{O}$ in $32 \%$ yield.

The synthetic scheme described here requires a reduced number of steps and leads to a higher yield with respect to the published procedure. This synthetic pathway should make it easier to access to functionalised target specific derivatives.

Crystals of $\mathrm{H}_{4}$ bpeda. $2 \mathrm{HCl} \cdot 3 \mathrm{H}_{2} \mathrm{O}, \mathbf{1}$, were obtained by slow evaporation of a concentrated aqueous solution of the ligand after adjusting the $\mathrm{pH}$ at $\sim 0.5$. The structure is shown in Fig. 1 . The structure shows that all the four carboxylates are protonated with $\mathrm{C}-\mathrm{OH}$ distances ranging from 1.201(4) to 1.215(4) $\AA$. The two remaining protons were located (from difference Fourier electron density map) on the two tertiary amine nitrogens.

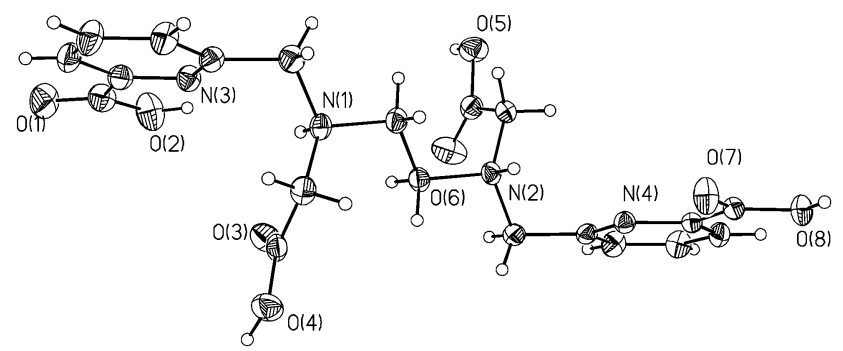

Fig. 1 Side view of the crystal structure of the diprotonated ligand $\mathrm{H}_{4}$ bpeda $2 \mathrm{HCl} \cdot 3 \mathrm{H}_{2} \mathrm{O}$, 1, with thermal ellipsoids at $30 \%$ probability.

\section{Metal complexes}

The gadolinium and europium complexes of bpeda were prepared by reacting the ligand with $\mathrm{LnCl}_{3} \cdot 6 \mathrm{H}_{2} \mathrm{O}(\mathrm{Ln}=\mathrm{Eu}, \mathrm{Gd})$ and adjusting the $\mathrm{pH}$ to $\sim 5$. The complexes are very soluble in water, methanol and ethanol. After elimination of the inorganic salts by filtration, the microcrystalline metal complexes isolated from isopropyl alcohol gave a satisfactory elemental analysis in agreement with the formation of analytically pure $1: 1$ complexes. While attempts to grow X-ray quality crystals of the Gd(III) complex of bpeda from various organic solvents and from water $(\mathrm{pH} \sim 6)$ were not successful, slow evaporation of a 1:1 mixture of $\mathrm{GdCl}_{3}$ and $\mathrm{H}_{4}$ bpeda at $\mathrm{pH} \sim 1$ lead to the isolation of crystals of the polynuclear complex $\left[\mathrm{Gd} \text { (bpeda) }\left(\mathrm{H}_{2} \mathrm{O}\right)_{2}\right]_{3}\left[\mathrm{Gd}\left(\mathrm{H}_{2} \mathrm{O}\right)_{6}\right]_{2} \mathrm{Cl}_{3}$ (2). Although, due to the poor quality of the crystals, the structure of $\mathbf{2}$ is not of very high quality, the coordination environment of the Gd ions is perfectly clear. The isolation of this species can be explained by the partial formation of the complex at very low $\mathrm{pH}$ and by the lower solubility of the pentametallic complex. The structure is shown in Fig. 2 and selected average bond distances and angles are set out in Table 2. In complex 2 three $\left[\mathrm{Gd}(\right.$ bpeda $\left.)\left(\mathrm{H}_{2} \mathrm{O}\right)_{2}\right]$ units are connected in a pentametallic structure by two hexa-aquo $\mathrm{Gd}^{3+}$ cations through four carboxylato bridges (Fig. 3). The $\left[\mathrm{Gd}(1)(\right.$ bpeda $\left.)\left(\mathrm{H}_{2} \mathrm{O}\right)_{2}\right]$ moiety is connected to both $\left[\mathrm{Gd}\left(\mathrm{H}_{2} \mathrm{O}\right)_{6}\right]^{3+}$ complexes through two different bridging carboxylate groups, while the remaining $\left[\mathrm{Gd}(\right.$ bpeda $\left.)\left(\mathrm{H}_{2} \mathrm{O}\right)_{2}\right]$ units are connected through carboxylate bridges each one to a different $\left[\mathrm{Gd}\left(\mathrm{H}_{2} \mathrm{O}\right)_{6}\right]^{3+}$ complex. This results in a polymetallic structure presenting a pseudo-twofold axis passing trough the $\mathrm{Gd}(1)$ ion. In the three [ Gd(bpeda) $\left.\left(\mathrm{H}_{2} \mathrm{O}\right)_{2}\right]$ units the gadolinium is ten-coordinated by the octadentate bpeda and two water molecules. The coor-

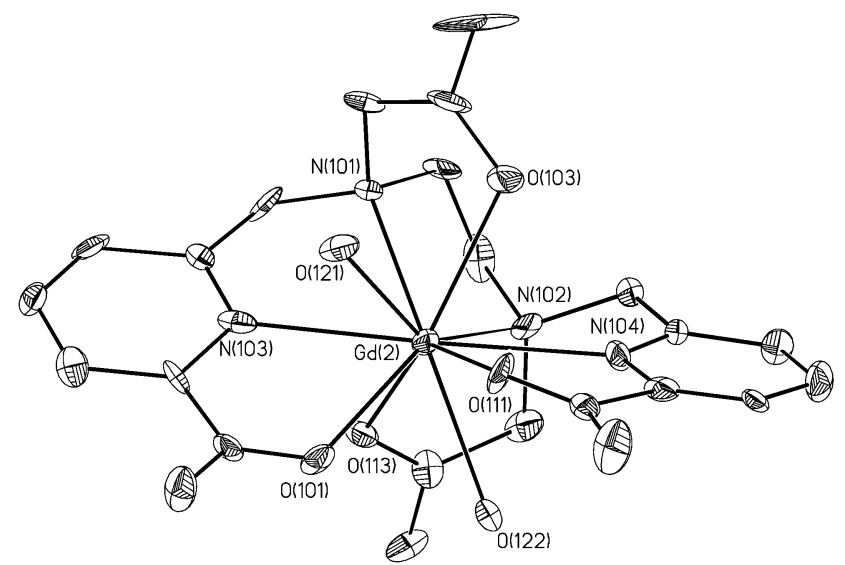

Fig. 2 View of the coordination environment of $\mathrm{Gd}(2)$ in the crystal structure of $\mathbf{2}$ with thermal ellipsoid at $30 \%$ probability.

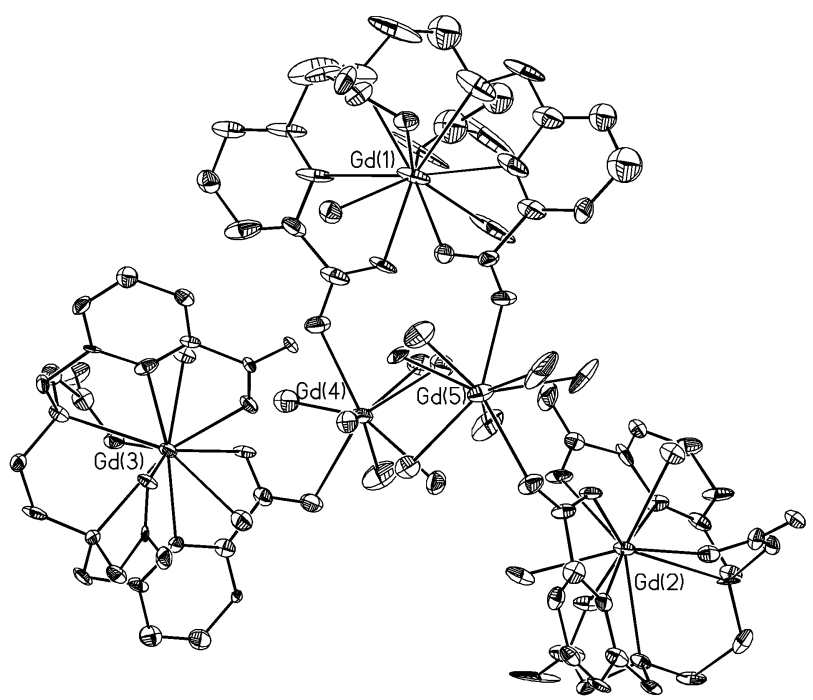

Fig. 3 View of the crystal structure of the complex 2 with thermal ellipsoid at $30 \%$ probability.

dination geometry can be described as a distorted bicapped square antiprism for the three $\left[\mathrm{Gd}(\right.$ bpeda $\left.)\left(\mathrm{H}_{2} \mathrm{O}\right)_{2}\right]$ units with the capping position occupied by the pyridyl nitrogens. The angle between the two square planes ranges from 4.1 to $4.5^{\circ}$. The average angle $\mathrm{N}_{\mathrm{py}}-\mathrm{Gd}-\mathrm{N}_{\mathrm{py}}$ is $172(2)^{\circ}$. The carboxylate arms are situated alternatively above and below the planes of the pyridyl units. The geometry around the $\left[\mathrm{Gd}\left(\mathrm{H}_{2} \mathrm{O}\right)_{6}\right]^{3+}$ cation is best described as a distorted dodecahedron.

Table 2 Average values of selected bond distances $(\AA)$ and angles $\left({ }^{\circ}\right)$ in complex 2

$\begin{array}{ll}\mathrm{Gd}-\mathrm{N}_{\mathrm{py}} & 2.61(2) \\ \mathrm{Gd}-\mathrm{N}_{\mathrm{am}} & 2.69(3) \\ \mathrm{Gd}-\mathrm{O}_{\mathrm{w}} & 2.52(2) \\ \mathrm{Gd}-\mathrm{O}_{\mathrm{CO}_{2}} & 2.46(3) \\ \mathrm{Gd}-\mathrm{O}_{\mathrm{pyCO}} & 2.43(4) \\ \mathrm{N}_{\mathrm{py}}-\mathrm{Gd}-\mathrm{N}_{\mathrm{py}} & 172(2)\end{array}$


The average $\mathrm{Gd}-\mathrm{N}_{\text {pyridyl }}$ distances (2.61(2) $\AA$ ) are slightly shorter than the average $\mathrm{M}-\mathrm{N}_{\text {amine }}$ distances found in other gadolinium polyaminopolycarboxylate complexes $(2.64$ $2.68 \AA)^{18-21}$ but similar to those found in the [Gd(tpaa)] complex (2.56(4) $\AA$ ) and in the $[\mathrm{Gd}($ tpatcn)] complex $(2.55(1) \AA)$. The values of the average $\mathrm{Gd}-\mathrm{N}_{\text {amine }}$ bond $(2.69(3) \AA$ ) are shorter than the values found for the distance $\mathrm{Gd}$-apical amine nitrogen in the [Gd(tpaa)] complexes (2.7886(19) A), but similar to the values found for the $\mathrm{Gd}-\mathrm{N}_{\text {amine }}$ in $[\mathrm{Gd}(\mathrm{tpatcn})](2.67(2) \AA)$. The average value of the $\mathrm{Gd}-\mathrm{O}_{\text {water }}$ distances (2.52(2) $\AA$ ) is in the range of the values found in other gadolinium polyaminopolycarboxylate complexes. The metal-ligand bond distances and the ligand conformation found in complex $\mathbf{2}$ differ from those found in the structure calculated by Mato-Iglesias and coworkers. ${ }^{10}$ This difference is explained by the difference in nuclearity and coordination number. While the solution structure of the complex $\left[\mathrm{Gd}(\right.$ bpeda $\left.)\left(\mathrm{H}_{2} \mathrm{O}\right)\right] \mathrm{K}$ is in agreement with the presence of only one coordinated water molecule, ${ }^{10}$ two water molecules are bound to each $\mathrm{Gd}(\mathrm{bpeda})$ unit in complex $\mathbf{2}$. This is probably a consequence of the presence of the $\mathrm{Gd}^{3+}$ ion (instead of $\mathrm{K}^{+}$) bound to the carboxylate oxygens of the Gd(bpeda) units.

\section{Protonation constants and stability constants}

The deprotonation constants of $\mathrm{H}_{4}$ bpeda defined as $K_{\mathrm{a} i}=$ $\left[\mathrm{H}_{6-i} \mathrm{~L}\right]^{2-i} /\left[\mathrm{H}_{5-i} \mathrm{~L}\right]^{1-i}[\mathrm{H}]^{+}$were determined to be $\mathrm{p} K_{\mathrm{a} 1}=2.9(1)$, $\mathrm{p} K_{\mathrm{a} 2}=3.5(1), \mathrm{p} K_{\mathrm{a} 3}=5.2(2)$ and $\mathrm{p} K_{\mathrm{a} 4}=8.5(1) .(0.1 \mathrm{M} \mathrm{KCl}$, $298 \mathrm{~K})$ by potentiometric titration. The titration curves of $\mathrm{H}_{4}$ bpeda and of its $\mathrm{Gd}(\mathrm{III})$ and $\mathrm{Ca}$ (II) complexes are shown in Fig. 4. Variable $\mathrm{pH}$ proton NMR spectroscopy of the ligand shows significant variations $(0.3 \mathrm{ppm})$ in the chemical shift of the methylene protons during the third and fourth protonation processes $(\mathrm{pH}=5-9)$ while no variation is observed during the first, second protonation processes $(\mathrm{pH}=2-5)$ (Fig. 5). Significant variations are observed for the chemical shifts of the three pyridyl protons $(\mathrm{H} 4, \mathrm{H} 5, \mathrm{H} 3: \sim 0.3 \mathrm{ppm})$ upon the first and second protonation processes $(\mathrm{pH}=2-5)$. The highest $\mathrm{p} K_{\mathrm{a}}(5.2(2), 8.5(1))$ may be identified with the protonation of the two aliphatic amine nitrogens, followed by the protonation of the carboxylates bound to the pyridines $(2.9(1), 3.5(1))$. The protonation of the two remaining carboxylates occurs at lower $\mathrm{pH}$ and the associate $\mathrm{p} K_{\mathrm{a}}$ could not be determined. The low value of $\mathrm{p} K_{\mathrm{a} 3}=5.2(2)$ associated to the protonation of the second aliphatic amine nitrogen can be explained by the presence of the 6-methyl-2-pyridinecarboxylic acid group. The assignment of $\mathrm{p} K_{\mathrm{a} 3}$ is in agreement with the solid-state crystal structure of the diprotonated ligand $\mathrm{H}_{6}$ bpeda $^{2+}$. Very similar values $\left(8.67(8)\right.$ and 5.53(3)) were found for the highest $\mathrm{p} K_{\mathrm{a}}$ 's of the ligand $N, N^{\prime}$-bis(2-pyridylmethyl)ethylenediamine- $N, N^{\prime}$ diacetic acid $\left(\mathrm{H}_{2}\right.$ bped $)$ where two of the carboxylate groups on edta are replaced by two pyridylmethyl moieties ${ }^{22}$ (Table 3 ). The

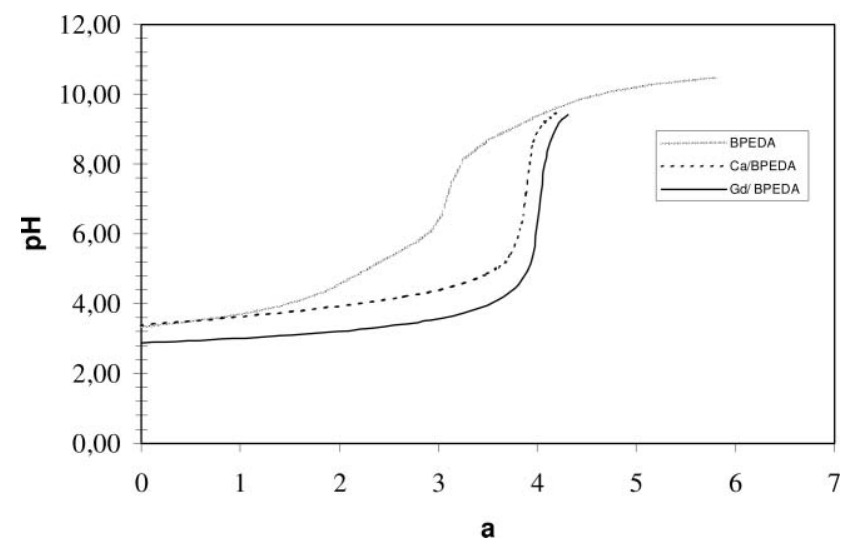

Fig. 4 Titration curves (pH vs $a$; $a=\mathrm{mol}$ of $\mathrm{OH}^{-} / \mathrm{mol}$ of bpeda) for $\mathrm{H}_{4}$ bpeda $(0.43 \mathrm{mM}$ ) and bpeda-M (where $\mathrm{M}=\mathrm{Ca}, \mathrm{Gd}$ ) solutions ([bpeda] $=0.43 \mathrm{mM},[\mathrm{M}]=0.38 \mathrm{mM})$.
Table 3 Values of $\mathrm{p} K_{\mathrm{a}}$ and $\log \beta$ for $\mathrm{H}_{4}$ bpdea and related ligands

\begin{tabular}{lllc}
\hline Ligand & $\mathrm{p} K_{\mathrm{a}}$ & $\log \beta_{\mathrm{GdL}}$ & $\log \beta_{\mathrm{CaL}}$ \\
\hline $\mathrm{H}_{4}$ bpdea $^{a}$ & $8.5(1), 5.2(2), 3.5(1), 2.9(1)$ & $15.1(3)$ & $9.4(1)$ \\
$\mathrm{H}_{2}$ bped $^{b}$ & $8.67(8), 5.53(3), 3.11(2)$ & $12.37(3)$ & \\
$\mathrm{H}_{4}$ edta $^{c}$ & $10.19,6.13,2.69,2.60$ & 17.4 & 10.5 \\
$\mathrm{H}_{3} \mathrm{nta}^{c}$ & $9.75,2.64,1.57$ & 11.4 & \\
$\mathrm{H}_{3}$ tpaa $^{d}$ & $4.11(6), 3.3(1), 2.5(2)$ & $10.2(2)$ & $8.5(2)$
\end{tabular}

${ }^{a}$ This work. ${ }^{b}$ From ref. $22 .{ }^{c}$ From ref. 23 which does not include experimental errors. ${ }^{d}$ From ref. 8.
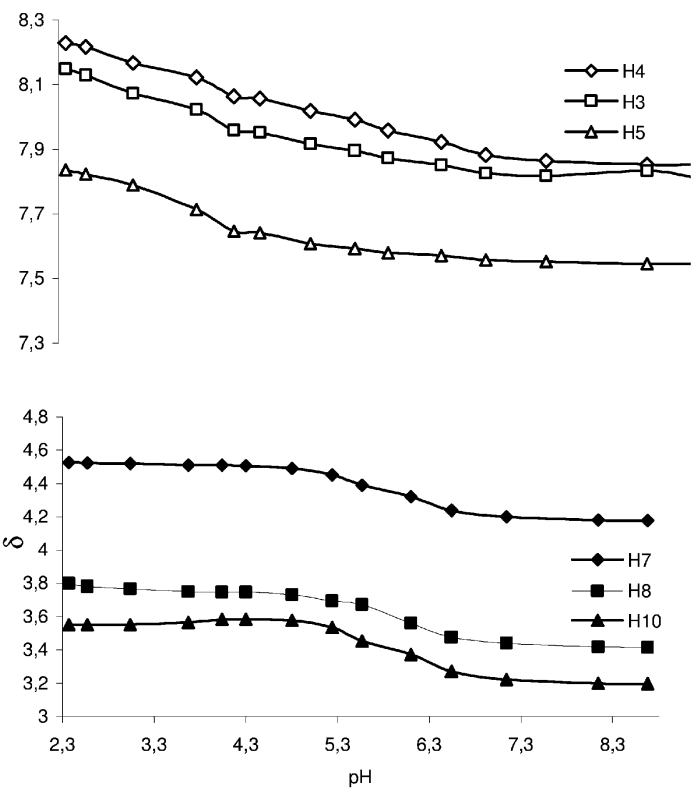

Fig. 5 Variation of the proton NMR chemical shift $\delta(\mathrm{ppm})$ of $\mathrm{H}_{4}$ bpeda vs. pH at $25^{\circ} \mathrm{C}$.

values of $\mathrm{p} K_{\mathrm{a} 1}$ and $\mathrm{p} K_{\mathrm{a} 2}$ are consistent with the values found for the protonation of the pyridylmethylcarboxylate groups in the tripodal ligand $\mathrm{H}_{3}$ tpaa $\left(\mathrm{p} K_{\mathrm{a} 1}=2.5(2), \mathrm{p} K_{\mathrm{a} 2}=3.3(1), \mathrm{p} K_{\mathrm{a} 3}=\right.$ 4.11(6)). The substitution of two of the carboxylate groups on edta with two methylpyridinecarboxylate groups leads to an important decrease of the basicity of the two amine nitrogen $\left(\mathrm{p} K_{\mathrm{a} 3}=6,42, \mathrm{p} K_{\mathrm{a} 4}=10.08\right.$ for edta $\left.{ }^{23}\right)$

The stability constants of the complexes formed between $\mathrm{Gd}$ (III) and $\mathrm{Ca}$ (II) ions and $\mathrm{H}_{4}$ bpeda have been determined by direct titration of $1: 1$ metal- $\mathrm{H}_{4}$ bpeda $\left(5.0 \times 10^{-4} \mathrm{M}\right)$ mixtures in the $\mathrm{pH}$ range $2.5-8.5$. Titration data could be fitted to eqns. (1) and (2):

$$
\begin{gathered}
\mathrm{Gd}^{3+}+\text { bpeda }^{4-} \leftrightarrow[\mathrm{Gd}(\text { bpeda })]^{-} ; \log \beta_{\mathrm{GdL}}=15.1(3) \\
\mathrm{Ca}^{2+}+\text { bpeda }^{4-} \leftrightarrow[\mathrm{Ca}(\text { bpeda })]^{2-} ; \log \beta_{\mathrm{CaL}}=9.4(1)
\end{gathered}
$$

The values of $\mathrm{pGd}=14.9$ and $\mathrm{pCa}=9.2\left(-\log [\mathrm{M}]_{\text {free }}\right.$ at $\mathrm{pH} 7.4$, $[\mathrm{M}]_{\text {total }}=1 \mu \mathrm{M}$, [tpaa $\left.]_{\text {total }}=10 \mu \mathrm{M}\right)$ which allow a straightforward comparison of complex stabilities in physiological conditions are similar to the values found for edta $(\mathrm{pGd}=15.3, \mathrm{pCa}=9.0)$.

The rather unexpected stability constant values show that in spite of the presence of two additional coordinating groups (two pyridyl nitrogens) in the ligand bpeda ${ }^{4-}$ with respect to the ligand edta ${ }^{4-}$ the stability of the gadolinium complex and of the calcium complex is lower for bpeda than edta $\left(\log \beta_{\mathrm{GdL}}=\right.$ $\left.17.4, \log \beta_{\mathrm{CaL}}=10.5\right)$. The decrease in stability is consistent with the decrease of the ligand $\mathrm{p} K_{\mathrm{a}}$ 's $\left(\sum \mathrm{p} K_{\mathrm{a}}=20.1\right.$ for $\mathrm{H}_{4}$ bpeda and 21.9 for $\mathrm{H}_{4}$ edta) suggesting that the lower stability of bpeda complexes is the result of a overall lower contribution to stability of the metal-nitrogen interactions. ${ }^{24}$ While the contribution of the 2-pyridylmethyl to stability was evaluated to $2.6 \mathrm{log}$ units for the $\mathrm{Gd}(\mathrm{III})$ complex of $\mathrm{H}_{2}$ bped by Caravan et $a l .{ }^{25}$ this work shows that the pyridyl functions do not 
contribute significantly to the complex stability when included in the 6-methyl-2-pyridinecarboxylic group. The similar values found for the stability constants of the gadolinium complexes of the nonadentate ligand $\mathrm{H}_{3}$ tpaa $\left(\log \beta_{\mathrm{GdL}}=10.2(2)\right)$ and of the tetradentate ligand $\mathrm{H}_{3} \mathrm{nta}\left(\log \beta_{\mathrm{GdL}}=11.4^{23}\right)$ are also consistent with a lack of contribution of the pyridyl to the stability in these pyridinecarboxylate systems. This is probably the consequence of a very low basicity of the pyridyl nitrogen due to the electron withdrawing effect of the carboxylate (protonation of the pyridine was not observed). The important effect of the ligand basicity on the thermodynamic stability of Gd(III) complexes has been recently evidenced by a study on a series of ligands with a similar structural motif. ${ }^{26}$

Although the stability of the $[\mathrm{Gd}(\text { bpeda })]^{-}$complex is probably rather low for the application as a contrast agent in MRI, the results showed here indicate that an appropriate substitution of the pyridine ring leading to an increased basicity of the pyridyl nitrogen should allow to improve the complex stability. Studies directed to improve the stability of these pyridinecarboxylate complexes through pyridine derivatization are in progress.

\section{EPR Spectroscopy}

Two typical EPR spectra of Gd(bpeda) in aqueous solution at Xand Q-band are reported in Fig. 6. The X-band spectra display very broad lines (apparent $\Delta H_{\mathrm{pp}} \sim 800-1200 \mathrm{G}$ depending on the temperature), centered at $g \sim 2$ as usual for $\mathrm{Gd}^{3+}$ complexes in aqueous solution. The line shape was notably non-Lorentzian, and could be better described as a superposition of two lines with different intensities, central fields and peak-to-peak widths. The more intense component (double integral of the EPR signal 213 times greater than the minor component) is also the broader one, with $\Delta H_{\mathrm{pp}}=720-840 \mathrm{G}$, and a $g$-factor close to $1.93\left(B_{\mathrm{c}}=\right.$ $3450-3540 \mathrm{G})$. The minor component is slightly sharper $\left(\Delta H_{\mathrm{pp}}=\right.$ $520-770 \mathrm{G})$ and appears at a lower magnetic field $\left(g \sim 2.25, B_{\mathrm{c}}=\right.$ 2890-3010 G).
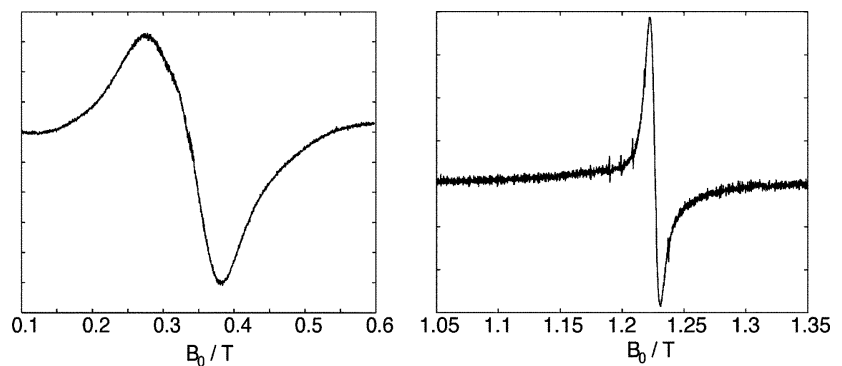

Fig. 6 Baseline-corrected EPR spectra of [Gd(bpeda)]K in aqueous solution: X-band $(9.44 \mathrm{GHz})$ at $297.4 \mathrm{~K}$ (left) and Q-band $(34 \mathrm{GHz})$ at $304.5 \mathrm{~K}$ (right). The small spikes in the Q-band spectrum are caused by traces of manganese in the clay that seals the EPR capillary tube.

At Q-band, the lines were much sharper, with an approximately Lorentzian shape. The apparent $g$-factor was about 1.983 $\left(B_{\mathrm{c}}=12250-12260 \mathrm{G}\right)$. The peak-to-peak width was between 90 and $110 \mathrm{G}$ depending on the temperature.

A large peak-to-peak width indicates a rapid transverse electron spin relaxation. At X-band, Gd(bpeda) is clearly among the fastest relaxing $\mathrm{Gd}^{3+}$ complexes to date (at X band $\Delta H_{\mathrm{pp}}=$ $604 \mathrm{G}$ at room temperature for $\left.\left[\mathrm{Gd}(\mathrm{dtpa})\left(\mathrm{H}_{2} \mathrm{O}\right)\right]^{2-}\right){ }^{27}$ At $\mathrm{Q}-$ band, its line width is similar to that of $\left[\mathrm{Gd}(\mathrm{dtpa})\left(\mathrm{H}_{2} \mathrm{O}\right)\right]^{2-}$, also fairly broad $\left(103 \mathrm{G}\right.$ at room temperature $\left.{ }^{27}\right)$. The electron spin relaxation has a negative impact on relaxivity, especially for the attractive macromolecular compounds with long rotational correlation times developed in the recent years. Thus our results show that the electronic properties of the Gd(bpeda) chelate are not favorable to its use as a synthon in such an application. This is in qualitative agreement with the NMR data of Muller and coworkers. ${ }^{10}$ Using the Solomon-Bloembergen-Morgan model modified by Powell et al. ${ }^{27}$ to analyze ${ }^{1} \mathrm{H}$ nuclear magnetic relaxation dispersion (NMRD) and ${ }^{17} \mathrm{O}$ NMR relaxation rates and chemical shifts, they obtained a transient zero-field splitting magnitude parameters $\Delta^{2}=1.2 \times 10^{20} \mathrm{~s}^{-2}$ and correlation time $\tau_{\mathrm{v}}=12.6 \mathrm{ps}$. With these numbers, one can calculate the transverse electron spin relaxation rates and the peak-to-peak width. Using Powell's equations we obtain $1053 \mathrm{G}$ at X-band and $279 \mathrm{G}$ at Q-band. With the more rigorous equations of Rast et al. ${ }^{28}$ the lines are not quite as broad, with $\Delta H_{\mathrm{pp}}=796 \mathrm{G}$ at X-band and $237 \mathrm{G}$ at Q-band.

Due to the non-Lorentzian character of the X-band spectra, we could not obtain an acceptable fit of the peak-to-peak widths and central fields using the approach of Rast et al. ${ }^{28}$ which can not account for the observed structure of the spectra. Furthermore, the Q-band data on their own are not sufficient since two or more EPR frequencies are required for a reliable analysis. However, the unattractive electronic properties of the complex do not warrant a very high frequency EPR study.

A slow electron spin relaxation was estimated from the NMRD profile of $[\mathrm{Gd}(\mathrm{tpatcn})]^{29}$ which has been confirmed by detailed EPR studies displaying for this complex the smallest peak-to-peak widths observed for gadolinium chelates (X-band $\Delta H_{\mathrm{pp}}=15 \mathrm{G}$ at room temperature). ${ }^{30}$ The remarkably slow electron relaxation of this complex is probably arising from the unusual coordination sphere containing six $\mathrm{N}$-donors associated to the complex symmetry.

However the fast electron spin relaxation observed for the [Gd(bpeda)]K complex indicate that the presence of pyridinecarboxylate chelating groups in itself does not lead to slow electron relaxation.

Work in progress is directed to further evaluate the influence on the electronic relaxation of these groups when they are included in different ligand architectures.

\section{Acknowledgements}

This work was supported by the Commissariat à l'Energie Atomique, Direction de l'Energie Nucléaire.

\section{References}

1 D. Parker, R. S. Dickins, H. Puschmann, C. Crossland and J. A. K. Howard, Chem. Rev., 2002, 102, 1977.

2 A. E. Merbach and E. Toth, The Chemistry of Contrast Agents in Medical Magnetic Resonance Imaging, Chichester, New York, 2001.

3 R. B. Lauffer, Chem. Rev., 1987, 87, 901.

4 S. Aime, M. Botta, M. Fasano and E. Terreno, Chem. Soc. Rev., 1998, 27, 19.

5 V. Comblin, D. Gilsoul, M. Hermann, V. Humblet, J. Vincent, M. Mesbahi, C. Sauvage and J. F. Desreux, Coord. Chem. Rev., 1999, 185-186, 451.

6 P. Caravan, J. J. Ellison, T. J. McMurry and R. B. Lauffer, Chem. Rev., 1999, 99, 2293.

7 Y. Bretonnière, M. Mazzanti, F. A. Dunand, A. E. Merbach and J. Pécaut, Chem. Commun., 2001, 621.

8 Y. Bretonnière, M. Mazzanti, F. A. Dunand, A. E. Merbach and J. Pécaut, Inorg. Chem., 2001, 40, 6737.

9 D. Messeri, M. P. Lowe, D. Parker and M. Botta, Chem. Commun., 2001, 2742

10 C. Platas, M. Mato-Iglesias, K. Djanashvili, N. R. Muller, L. Vander Elst, J. A. Peters, A. de Blas and T. Rodriguez-Blas, Chem. Eur. J., 2004, 10, 3579.

11 R. Fornasier, D. Milani, P. Scrimin and U. Tonellato, J. Chem. Soc., Perkin Trans. 2, 1986, 233.

12 Bruker: SMART: Software package for use with the SMART diffractometer, Madison, WI, USA, 1995.

13 G. M. Sheldrick, SHELXTL-Plus, Göttingen, Germany, 1994

14 A. E. Martell and R. M. Smith, Critical Stability Constants, Plenum Press, New York, 1976

15 P. Gans, A. Sabatini and A. Vacca, Talanta, 1996, 43, 1739.

16 P. Gans, A. Sabatini and A. Vacca, HYPERQUAD2000, Leeds, UK and Florence, Italy, 2000.

17 A. Borel and L. Helm, NMRICMA 3.0.3., EPFL, 2004.

18 C. A. Chang, L. C. Francesconi, M. F. Malley, K. Kumar, J. Z. Gougoutas, M. F. Tweedle, D. W. Lee and L. J. Wilson, Inorg. Chem., 1993, 32, 3501 . 
19 K. Kumar, C. A. Chang, L. C. Francesconi, D. D. Dischino, M. F. Malley, J. Z. Gougoutas and M. F. Tweedle, Inorg. Chem., 1994, 33, 3567.

20 F. Uggeri, S. Aime, P. L. Anelli, M. Botta, M. Brocchetta, C. de Haën, G. Ermondi, M. Grandi and P. Paoli, Inorg. Chem., 1995, 34, 633.

21 M. S. Konings, W. C. Dow, D. B. Love, K. N. Raymond, S. C. Quay and S. M. Rocklage, Inorg. Chem., 1990, 29, 1488.

22 P. Caravan, S. Rettig and C. Orvig, Inorg. Chem., 1997, 36, 1306.

23 A. Bianchi, L. Calabi, F. Corana, S. Fontana, P. Losi, A. Maiocchi, L. Paleari and B. Valtancoli, Coord. Chem. Rev., 2000, 204, 309

24 G. R. Choppin, J. Alloys Compd., 1997, 249, 1.
25 P. Caravan, P. Mehrkhodavandi and C. Orvig, Inorg. Chem., 1997, 36, 1316 .

26 D. M. Doble, M. Melchior, B. O’Sullivan, C. Siering, J. Xu, V. Pierre and K. N. Raymond, Inorg. Chem., 2003, 42, 4930.

27 H. D. Powell, O. M. N. Ni Dhubhghaill, D. Pubanz, L. Helm, Y. S Lebedev, W. Schlaepfer and A. E. Merbach, J. Am. Chem. Soc., 1996, 118, 9333.

28 S. Rast, A. Borel, L. Helm, E. Belorizky, P. H. Fries and A. E. Merbach, J. Am. Chem. Soc., 2001, 123, 2637.

29 C. Gateau, M. Mazzanti, J. Pécaut, F. Dunand, A and L. Helm, Dalton Trans., 2003, 2428.

30 A. Borel, H. Kang, R. B. Clarkson, M. Mazzanti, C. Gateau, and R. L. Belford, J. Phys. Chem., in press. 